J-SISKO TECH

Jurnal Teknologi Sistem Informasi dan Sistem Komputer TGD

P:ISSN : 2621-8976 E-ISSN : 2615-5133

Vol.3, No.1, Januari 2020, pp.148-162

\title{
Analisis Kesiapan Satuan Pendidikan Kejuruan Dalam Penerapan Kurikulum Aceh Menggunakan Metode Fuzzy Tsukamoto Di Kota Lhokseumawe
}

\author{
Zahratul Fitri \\ Program Studi Pendidikan Informatika, STKIP Bumi Persada Lhokseumawe \\ Jln. Haji Nafi Gg Buntu No. 39 Tumpok Dalam, Cunda, Lhokseumawe, Aceh \\ Email : zahratulfitrihumaira@gmail.com
}

\begin{abstract}
Abstrak
Kurikulum Aceh disusun sebagai aktualisasi Qanun Aceh Nomor 9 Tahun 2015 Tentang Perubahan atas Qanun Aceh Nomor 11 Tahun 2014 Tentang Penyelenggaraan Pendidikan memberi kewenangan kepada Pemerintah Propinsi Aceh. Kurikulum Aceh adalah kurikulum inovasi dari kurikulum 2013 yang hanya diterapkan di propinsi Aceh. Kurikulum tersebut disusun untuk mewujudkan generasi muda Aceh yang berkompeten serta menjunjung tinggi nilai-nilai ke-Acehan yang islami. Propinsi Aceh merupakan propinsi paling barat Indonesia, memiliki kekayaan alam yang melimpah dan letaknya yang sangat strategis adalah acuan utama pemerintah untuk mempersiapkan generasinya dalam rangka mendukung cita-cita nasional menjadikan bonus demografi pada tahun 2028 sampai 2031 menjadi kekuatan bangsa. Untuk mewujudkan cita-cita dimaksud perlu adanya persiapan generasi muda sejak dini. Pendidikan adalah instrumen utama yang penting diperhatikan, semua aspek mestilah bersinergi untuk mewujudkan pendidikan yang berkualitas.

Adapun fokus pada penelitian ini adalah kesiapan satuan pendidikan kejuruan di Kota Lhokseumawe. Peneliti menganalisis indikator-indikator yang berhubungan langsung dengan tingkat kesiapan sekolah dalam menerapkan kurikulum Aceh. Indikator-indikator dimaksud tidak keluar dari delapan standar pendidikan nasional yang telah dirumuskan oleh Badan Standar Nasional Pendidikan (BSNP), yaitu standar isi, standar proses, standar kompetensi lulusan, standar pendidik dan tenaga kependidikan, standar sarana dan prasarana, standar pengelolaan, standar pembiayaan dan standar penilaian. Kedelapan standar tersebut akan dijabarkan dalam indikator-indikator dan sub indikator.

Dalam penelitian ini, metode yang digunakan adalah Metode Fuzzy Tsukamoto, dimana Setiap konsekuen pada aturan yang berbentuk IF-THEN harus direpresentasikan dengan suatu himpunan fuzzy dengan fungsi keanggotaan yang monoton. Sebagai hasilnya, output hasil inferensi dari tiap-tiap aturan diberikan secara tegas berdasarkan a-predikat. Hasil akhirnya diperoleh dengan menggunakan rata-rata terbobot. Konsep dasar dari penelitian ini adalah penerapan logika samar (Fuzzy Logic) yaitu Himpunan Samar (Fuzzy Sef) dan metode Penarikan Kesimpulan Samar (Fuzzy Inference system) Tsukamoto untuk membantu menentukan tingkat kesiapan satuan pendidikan kejuruan dalam penerapan kurikulum Aceh di Kota Lhokseumawe.
\end{abstract}

Kata Kunci : Kurikulum Aceh, Fuzzy Tsukamoto. 


\begin{abstract}
The Aceh curriculum is structured as the actualization of the Aceh Qanun Number 9 of 2015 concerning Amendments to the Aceh Qanun Number 11 of 2014 concerning the Implementation of Education granting authority to the Aceh Provincial Government. The Aceh curriculum is an innovation curriculum from the 2013 curriculum which is only applied in the province of Aceh. The curriculum is structured to realize the competent young generation of Aceh and uphold Islamic Acehan values. Aceh Province is the westernmost province of Indonesia, has abundant natural wealth and a very strategic location is the main reference of the government to prepare its generation in order to support national ideals to make demographic bonuses in 2028 to 2031 become the strength of the nation. To realize these goals, it is necessary to prepare young people early on. Education is the main instrument that is important to note, all aspects must work together to create quality education.

The focus of this research is the readiness of the vocational education unit in Lhokseumawe City. The researcher analyzes the indicators that are directly related to the level of school readiness in implementing the Aceh curriculum. These indicators do not come out of the eight national education standards that have been formulated by the National Education Standards Agency (BSNP), namely content standards, process standards, graduate competency standards, educator and education personnel standards, facilities and infrastructure standards, management standards, financing standards and assessment standards. The eight standards will be described in indicators and sub-indicators.

In this study, the method used is the Tsukamoto Fuzzy Method, where each consequent to the rules in the form of IF-THEN must be represented by a fuzzy set with a monotonous membership function. As a result, the output of the inference results from each rule is given expressly based on the a-predicate. The final result is obtained using a weighted average. The basic concept of this research is the application of fuzzy logic (Fuzzy Logic) and the Tsukamoto Fuzzy Interference Method to help determine the level of readiness of the vocational education unit in the application of the Aceh curriculum in the City of Lhokseumawe
\end{abstract}

Keywords: Kurikulum Aceh, Fuzzy Tsukamoto.

\title{
1. Pendahuluan
}

Kurikulum memiliki peranan penting dalam pendidikan, dalam bukunya Pengembangan Kurikulum Teori dan Praktik menrangkan bahwa kurikulum adalah program dan pengalaman belajar serta hasil-hasil belajar yang di harapkan yang diformulasikan melalui pengetahuan dan kegiatan yang tersusun secara sistematis, di berikan kepada siswa di bawah tanggung jawab sekolah untuk membantu pertumbuhan atau perkembangan pribadi dan kompetensi sosial peserta didik. Dengan demikian dapat dikatakan bahwa kurikulum merupakan pedoman penyelenggaraan pembelajaran dalam rangka mencapai tujuan pendidikan. Dalam sejarah pendidikan Indonesia, ada beberapa jenis kurikulum yang telah disusun dan diterapkan oleh pemerintah Indonesia, yang terakhir adalah kurikulum 2013 yang ditetapkan pada Tahun Ajaran 2013/2014 melalui Peraturan Menteri Pendidikan Dan Kebudayaan RI nomor 81A tahun 2013.

Berdasarkan standar-standar yang telah ditetapkan dalam kurikulum 2013, pemerintah Aceh berinovasi dalam penerapan kurikulum 2013 dengan memasukkan nilai-nilai kearifan lokal dalam kurikulum tanpa keluar dari standar yang telah ditetapkan, kurikulum tersebut dinamakan kurikulum Aceh. Hal tersebut tercantum dalam Qanun Aceh Nomor 9 Tahun 2015 Tentang Perubahan atas Qanun Aceh Nomor 11 Tahun 2014 Tentang Penyelenggaraan Pendidikan memberi kewenangan kepada Pemerintah Propinsi Aceh untuk menyusun dan mengembangkan kurikulum yang berkarakter ke-Acehan. Karakter utama yang dibangun dalam kurikulum Aceh adalah konsep pembelajaran pendekatan Scientific Dinul Islam. Pemerintah 
Aceh melalui Dinas Pendidikan telah melakukan sosialisasi kurikulum Aceh di Kota Lhokseumawe pada bulan Januari 2018. Dalam sosialisasi dimaksud dihadiri oleh Kepala Sekolah dan Wakil Kepala Sekolah Bidang Kurikulum semua satuan pendidikan kejuruan seKota Lhokseumawe. Dalam penerapannya, kurikulum Aceh diselenggarakan melalui pendekatan Work Based Learning (WBL) ke-Acehan, seperti memasukkan ayat-ayat suci AlQuran yang sesuai dalam materi pembelajaran, serta mengutamakan karakter peserta didik yang Islami dan konsisten baik dilingkungan sekolah maupun diluar sekolah.

Peranan satuan pendidikan dalam penerapan kurikulum Aceh sangat penting. Aspek kesiapan satuan pendidikan perlu diukur supaya penerapan kurikulum Aceh sesuai dengan standar yang telah ditetapkan. Ada beberapa indikator yang perlu diukur dalam aspek kesiapan satuan pendidikan diantaranya adalah kesiapan administrasi satuan pendidikan, kesiapan administrasi pembelajaran, kesiapan fasilitas dan kesiapan sumber daya manusia (pendidik dan tenaga kependidikan). Pada kesempatan ini peneliti memfokuskan kepada satuan pendidikan kejuruan, karena satuan pendidikan kejuruan memiliki tujuan untuk menciptakan tanaga kerja dan wirausahawan, hal ini sejalan dengan cita-cita bangsa Indonesia menjadikan bonus demografi sebagai kekuatan bangsa. Satuan pendidikan kejuruan perlu dipersiapkan secara optimal untuk meraih tujuan yang diamanatkan dalam kurikulum Aceh, yaitu mewujudkan peserta didik yang berkompeten dan islami. Oleh karena itu dipandang perlu adanya analisa sejak dini terhadap satuan pendidikan kejuruan. Pada penelitian ini peneliti terfokus kepada analisis kesiapan satuan pendidikan kejuruan dalam penerapan kurikulum Aceh di Kota Lhokseumawe.

Dalam penelitian ini, metode yang digunakan adalah Metode Fuzzy Tsukamoto, dimana Setiap konsekuen pada aturan yang berbentuk IF-THEN harus direpresentasikan dengan suatu himpunan fuzzy dengan fungsi keanggotaan yang monoton. Sebagai hasilnya, output hasil inferensi dari tiap-tiap aturan diberikan secara tegas berdasarkan a-predikat. Hasil akhirnya diperoleh dengan menggunakan rata-rata terbobot. Konsep dasar dari penelitian ini adalah penerapan logika samar (Fuzzy Logic) yaitu Himpunan Samar (Fuzzy Sef) dan metode Penarikan Kesimpulan Samar (Fuzzy Inference system) Tsukamoto untuk membantu menentukan tingkat kesiapan satuan pendidikan kejuruan dalam penerapan kurikulum Aceh di Kota Lhokseumawe.

\section{METODE PENELITIAN}

\subsection{Definisi Fuzzy Logic}

Fuzzy logic (logika samar) adalah suatu cara yang tepat untuk memetakan suatu ruang input ke dalam suatu ruang output. Beberapa keunggulan dari logika samar adalah konsepnya sederhana dan mudah dimengerti, memiliki toleransi terhadap data-data yang tidak tepat, dan logika samar didasarkan pada bahasa alami[2].

Berikut ini adalah alasan - alasan yang telah diuraikan mengapa digunakannya logika Fuzzy :

a) Konsep logika fuzzy mudah dimengerti. Konsep Matematis yang mendasari penalaran fuzzy sangat sederhana dan mudah dimengerti

b) Logika fuzzy sangat fleksibel

c) Logika fuzzy memiliki toleransi terhadap data-data yang tidak tepat.

d) Logika fuzzy mampu memodelkan fungsi-fungsi nonlinear yang sangat kompleks. Logika fuzzy dapat membangun dan mengaplikasikan pengalaman-pengalaman para pakar secara langsung tanpa harus melalui proses pelatihan.

e) Logika fuzzy dapat bekerjasama dengan teknik-teknik kendali secara konvensional.

f) Logika fuzzy didasarkan pada bahasa alami

\subsection{Himpunan Fuzzy}

Pada himpunan tegas (crisp), nilai keanggotan suatu item $x$ dalam suatu himpunan $A$ yang sering ditulis dengan $\mu \mathrm{A}[\mathrm{x}]$, memiliki 2 kemungkinan yaitu [2]:

J-SISKO TECH Vol. 3, No. 1, $2020: 148-162$ 
a) Satu (1), yang berarti bahwa suatu item menjadi anggota dalam suatu himpunan, atau

b) Nol (0), yang berarti bahwa Suatu item tidak menjadi anggota dalam suatu himpunan

Jika pada himpunan crisp, nilai keanggotaan hanya ada 2 kemungkinan yaitu 0 dan1, maka pada himpunan fuzzy nilai keanggotaan terletak pada rentang 0 sampai1. Himpunan fuzzy memiliki 2 atribut:

a) Linguistik, yaitu penamaan suatu grup yang mewakili suatu keadaan atau kondisi tertentu dengan menggunakan bahasa alami, seperti : MUDA, PAROBAYA, TUA

b) Numeris, yaitu suatu nilai (angka) yang menunjukan ukuran dari suatu variable seperti: 40 , 25, 35.

Adapun hal-hal yang terdapat pada system fuzzy adalah sebagai berikut :

a) Variabel Fuzzy, merupakan variable yang hendak dibahas dalam suatu sistem fuzzy, seperti umur, temperatur, dsb.

b) Himpunan Fuzzy, merupakan suatu grup yang mewakili suatu kondisi atau keadaan tertentu dalam suatu variable fuzzy.

c) Semesta Pembicaraan, adalah keseluruhan nilai yang diperbolehkan untuk dioperasikan dalam suatu variable fuzzy.

d) Domain, adalah keseluruhan nilai yang diijinkan dalam semesta pembicaraan dan boleh dioperasikan dalam suatu himpunan fuzzy.

Pada himpunan fuzzy derajat keanggotaan suatu elemen berada pada rentang $[0,1]$. Artinya bisa saja nilai keanggotaan suatu elemen pada himpunan fuzzy bernilai $0.1,0.5,0.75$, dll. Intinya derajat keanggotaan suatu elemen pada himpunan fuzzy tidak harus hanya 0 dan 1.

Misalkan :

$X=\{$ kodok, kecoa, kucing, anjing, harimau $\}$,

$A$ adalah subset dari $X$,

$\mathrm{A}=$ himpunan binatang yang lazim dijadikan hewan peliharaan di rumah.

Maka derajat keanggotaan di A untuk kodok=0.3, kecoa=0, kucing=1, anjing=1, harimau $=0.5$ (nilai-nilai ini berdasarkan pendapat penulis, sehingga bisa jadi pembaca memiliki nilai derajat keanggotaan yang berbeda dengan penulis).

\subsection{Metode Tsukamoto}

Setiap konsekuen pada aturan yang berbentuk IF-THEN harus direpresentasikan dengan suatu himpunan fuzzy dengan fungsi keanggotaan yang monoton. Sebagai hasilnya, output hasil inferensi dari tiap-tiap aturan diberikan secara tegas berdasarkan $\alpha$-predikat.Hasil akhirnya diperoleh dengan menggunakan rata-rata terbobot.

Konsep dasar dari analisis ini adalah penerapan logika samar (Fuzzy Logic) yaitu Himpunan Samar (Fuzzy Sef) dan metode Penarikan Kesimpulan Samar (Fuzzy Inference system) Tsukamoto untuk membantu menentukan efektifitas penerapan kurikulum Aceh di SMKN Kota Lhokseumawe. Secara umum bentuk model fuzzy tsukamoto adalah sebagai berikut:

If $(X$ is $A)$ and $(Y$ is $B)$ then ( $Z$ is $C)$

Dimana A, B, C adalah himpunan Fuzzy.

Misalkan diketahui 2 rule berikut:

IF $\left(x\right.$ is $\left.A_{1}\right)$ AND ( $y$ is $\left.B_{1}\right)$ THEN ( $z$ is $\left.C_{1}\right)$

IF ( $x$ is $\left.A_{2}\right)$ AND ( $y$ is $\left.B_{2}\right)$ THEN ( $z$ is $\left.C_{2}\right)$

Dalam inferensinya, metode Tsukamoto menggunakan tahapan berikut :

a. Fuzzyfikasi

Yaitu Proses untuk mengubah input sistem yang mempunyai nilai tegas menjadi variabel linguistik menggunakan fungsi keanggotaan yang disimpan dalam basis pengetahuan fuzzy. [3]

b. Pembentukan basis pengetahuan fuzzy (Rule dalam bentuk IF... THEN) 
Contoh:

IF (X IS A) and (Y IS B) Then (Z IS C) Dimana A, B, dan C adalah himpunan fuzzy.

c. Mesin Inferensi

Menggunakan fungsi implikasi MIN untuk mendapatkan nilai $\alpha$-predikat tiap-tiap rule ( $\alpha 1$, $\alpha 2, \alpha 3, \ldots$ an). Kemudian masing - masing nilai $\alpha$-predikat ini digunakan untu menghitung keluaran hasil inferensi secara tegas (crisp) masing-masing rule $\left(z_{1}, z_{2}, z_{3}, \ldots z_{n}\right)$.

d. Defuzzyfikasi

Menggunakan metode Rata-Rata (Average)

$$
Z^{*}=\frac{\sum a_{i} z_{i}}{\sum a_{i}}
$$

\subsection{Kurikulum Aceh}

Kurikulum Aceh adalah kurikulum inovasi dari kurikulum 2013 yang hanya diterapkan di propinsi Aceh yang disusun sebagai aktualisasi Qanun Aceh Nomor 9 Tahun 2015 Tentang Perubahan atas Qanun Aceh Nomor 11 Tahun 2014 Tentang Penyelenggaraan Pendidikan memberi kewenangan kepada Pemerintah Propinsi Aceh. Kurikulum Aceh bertujuan untuk mewujudkan lulusan menjadi angkatan kerja yang kompeten yaitu memiliki akhlak mulia, pengetahuan dan keterampilan serta mampu mengaktualisasikan nilai-nilai ke-Acehan yang islami dalam kehidupan sehari-hari. Oleh karena itu, kurikulum Aceh juga disebut kurikulum Edutechonopreneurship [15].

Dalam penerapan kurikulum Aceh tetap mengacu kepada acuan yang telah ditetapkan dalam kurikulum 2013, seperti yang tercantum pada lampiran IV Permendikbud nomor $81 \mathrm{~A}$ tahun 2013 yaitu terdiri atas lima pengalaman belajar pokok yaitu mengamati, menanya, mengumpulkan informasi, mengasosiasi, dan mengkomunikasikan. Kondisi pembelajaran yang diharapkan tercipta diarahkan untuk mendorong peserta didik dalam mencari tahu dari berbagai sumber melalui observasi dan bukan hanya dari guru. Untuk mencapai tujuan maksimal kurikulum 2013 ini adalah pada konsp pembelajaran pendekatan saintifik [14].

Dalam bukunya Sukses Mengimplementasikan Kurikulum 2013 dijelaskan bahwa pembelajaran dengan pendekatan saintifik adalah proses pembelajaran yang dirancang sedemikian rupa agar peserta didik secara aktif mengkonstruk konsep, hukum atau prinsip melalui tahapan-tahapan mengamati (untuk mengidentifikasi atau menemukan masalah), merumuskan masalah, mengajukan atau merumuskan hipotesis, mengumpulkan data dengan berbagai teknik, menganalisis data, menarik kesimpulan dan mengkomunikasikan konsep, hukum atau prinsip yang "ditemukan" [12]. Pendekatan saintifik dimaksudkan memberikan pemahaman kepada peserta didik dalam mengenal, memahami berbagai materi menggunakan pendekatan ilmiah, bahwa informasi bisa berasal dari mana saja, kapan saja, tidak bergantung pada informasi guru.

Penerapan pendekatan saintifik dalam pembelajaran melibatkan keterampilan proses seperti mengamati, mengklasifikasi, mengukur, meramalkan, menjelaskan, dan menyimpulkan. Dalam melaksanakan proses-proses tersebut, bantuan guru diperlukan.Akan tetapi bantuan guru tersebut harus semakin berkurang dengan semakin bertambah dewasanya siswa atau semakin tingginya kelas siswa. Pembelajaran dengan metode saintifik memiliki karakteristik sebagai berikut:

1. Berpusat pada siswa.

2. Melibatkan keterampilan proses sains dalam mengonstruksi konsep, hokum atau prinsip.

J-SISKO TECH Vol. 3, No. 1, $2020: 148-162$ 
3. Melibatkan proses-proses kognitif yang potensial dalam merangsang perkembangan intelek, khususnya keterampilan berfikir tingkat tinggi siswa.

4. Dapat mengembangkan karakter siswa.

2.5. Langkah-Langkah Umum Pembelajaran Pendekatan Saintifik

Permendikbud nomor 103 tahun 2014, dijelaskan bahwa terdapat lima langkah dalam pendekatan santifik, yaitu mengamati (observing), menanya (questioning), mengumpulkan informasi/mencoba (experimenting), menalar atau mengasosiasi (associating), dan mengkomunikasikan (communicating). Pendekatan saintifik memiliki beberapa kelebihan yaitu proses pembelajaran lebih terpusat pada siswa sehingga memungkinkan siswa aktif dan kreaktif dalam pembelajaran, langkah-langkah pembelajarannya sistematis sehingga memudahkan guru untuk memanajemen pelaksanaan pembelajaran, memberi peluang guru untuk lebih kreatif dan mengajak siswa untuk aktif dengan berbagai sumber belajar, langkahlangkah pembelajaran melibatkan keterampilan proses sains dalam mengonstruksi konsep hukum atau prinsip, proses pembelajarannya melibatkan proses-proses kognitif yang potensial dalam merangsang perkembangan intelek khususnya keterampilan berpikir tingkat tinggi siswa, dapat mengembangkan karakter siswa dan penilaiannya mencakup semua aspek.

Untuk mata pelajaran, materi, atau situasi tertentu, sangat mungkin pendekatan ilmiah ini tidak selalu tepat diaplikasikan secara prosedural. Pada kondisi seperti ini, tentu saja proses pembelajaran harus tetap menerapkan nilai-nilai atau sifat-sifat ilmiah dan menghindari nilainilai atau sifat-sifat nonilmiah. Pendekatan saintifik dalam pembelajaran disajikan sebagai berikut:
a. Mengamati
b. Menanya
c. Mengumpulkan Informasi/Experiment
d. Mengasosiaikan/Mengolah Informasi
e. Mengkomunikasikan

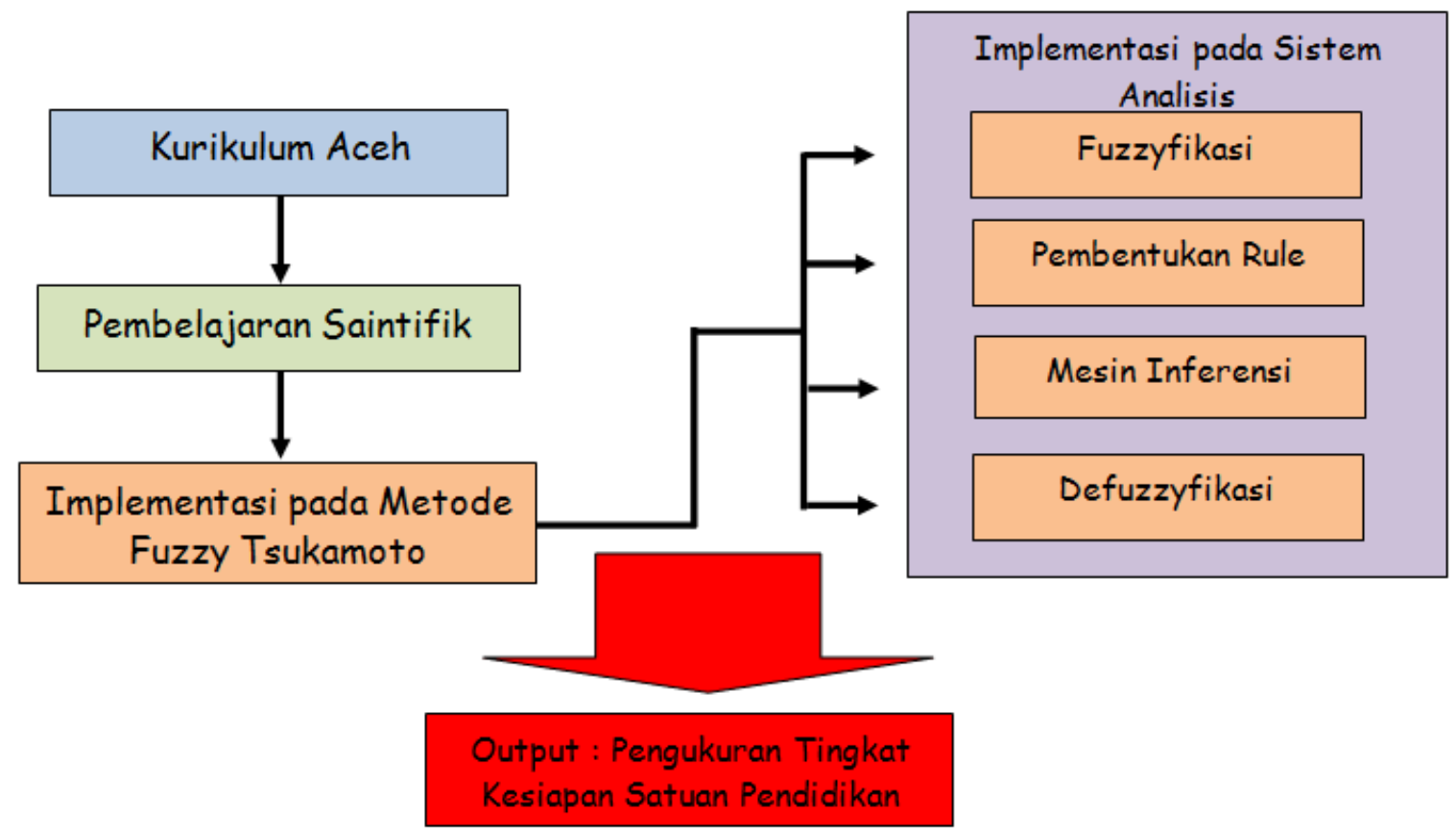

Gambar 1. Alur Umum Penelitian 


\section{ANALISA DAN HASIL}

Peneliti melakukan penelitian selama 8 bulan yang terfokus pada tingkat kesiapan Satuan Tingkat Kejuruan terhadap penerapan kurikulum dengan melihat hasil jumlah kuesionaer data SMK (Sekolah Menengah Kejuruan) 3 Lhokseumawe, Aceh. Yaitu pengumpulan data dengan cara inventarisir bukti pembelajaran, dokumentasi hasil belajar siswa, pengamatan proses pembelajaran, dan wawancara dengan informan. Pihak - pihak yang dijadikan informan dalam penelitian ini adalah: (a). Kepala dinas Pendidikan Kota Lhokseumawe; (b). Kepala Sekolah SMK Kota Lhokseumawe; (c). Guru Sekolah SMK Kota Lhokseumawe-Aceh; (d). Siswa Sekolah SMK Kota Lhokseumawe.

Program Simulasi dalam analisis ini dibangun dengan menggunakan komputer Prosesor Intel Core i5, $2.60 \mathrm{GHz}$. RAM, 2 GB. VGA, 1 GB, netbeans tools dan menggunakan bahasa pemrograman Java. Pada analisa yang telah dilakukan menggunakan simulasi algoritma Fuzzy Tsukamoto. Berdasarkan data yang sesuai dari kriteria yang diambil dari hasil pengumpulan data, himpunan fuzzy ini merupakan kesatuan dari yang mewakili keadaan tertentu dalam sebuah variable fuzzy. Pada proses ini, telah digunakan himpunan fuzzy dalam dua variable linguistic yaitu Siap atau Tidak. Pembentukan himpunan fuzzy inilah yang akan disesuaikan berdasarkan pendapat sang pakar (Santika et al, 2015. Berikut ini data yang diterima dari hasil pengumpulan data penelitian.

Tabel 1. Rentang Nilai Kriteria

\begin{tabular}{|l|c|}
\hline \multicolumn{1}{|c|}{ Kriteria } & Nilai Range \\
\hline Standar Satuan Pendidikan & $0-4$ \\
\hline Standar Guru dan Tendik & $0-4$ \\
\hline Standar Sarana dan Prasarana & $0-4$ \\
\hline Standar Kerjasama & $0-4$ \\
\hline
\end{tabular}

Tabel 2. Contoh Kasus pada inferensi fuzzy Tsukamoto

\begin{tabular}{|l|c|}
\hline \multicolumn{1}{|c|}{ Variable Input } & Nilai Input \\
\hline Standar Satuan Pendidikan & 3,0 \\
\hline Standar Guru dan Tendik & 3,0 \\
\hline Standar Sarana dan Prasarana & 3,0 \\
\hline Standar Kerjasama & 3,0 \\
\hline
\end{tabular}

Berikut ini adalah data uji coba dalam pengimputan pada system yang parameter nilai inputnya diberikan oleh sang pakar.

\section{Himpunan Fuzzy}

Aturan - aturan fuzzy berupa implikasi himpunan fuzzy yang akan menjadi dasar dari perhitungan suatu sistem fuzzy. Aturan-aturan ini berbentuk JIKA ..., MAKA ..., Misalkan pada system fuzzy yang Akan dibangun menggunakan empat aturan fuzzy, yakni:

\section{Himpunan Fuzzy}

\begin{tabular}{lc}
\hline \multicolumn{1}{c}{ Variable Input } & Nilai Input \\
Standar Satuan Pendidikan & Terakreditasi/Tidak \\
Standar Guru dan Tendik & Bersertifikasi/Tidak \\
Standar Sarana dan Prasarana & Lengkap/Tidak \\
Standar Kerjasama & Diterapkan/Tidak \\
\hline
\end{tabular}

J-SISKO TECH Vol. 3, No. 1, $2020: 148-162$ 
Berikut adalah Basis Aturan atau Rule Base yang dibangun dalam metode Fuzzy Tsukamoto:

\begin{tabular}{|c|c|c|c|c|c|}
\hline Rule & $\begin{array}{c}\text { Standar Satuan } \\
\text { Pendidikan }\end{array}$ & $\begin{array}{l}\text { Standar Guru } \\
\text { dan Tendik }\end{array}$ & $\begin{array}{c}\text { Standar } \\
\text { Sarana dan } \\
\text { Prasarana }\end{array}$ & $\begin{array}{c}\text { Standar } \\
\text { Kerjasama }\end{array}$ & Kesiapan \\
\hline$\overline{1 .}$ & TERAKREDITASI & BERSERTIFIKASI & LENGKAP & DITERAPKAN & $\overline{Y A}$ \\
\hline 2. & $\begin{array}{c}\text { TIDAK } \\
\text { TERAKREDITASI }\end{array}$ & BERSERTIFIKASI & LENGKAP & DITERAPKAN & TIDAK \\
\hline 3. & TERAKREDITASI & $\begin{array}{c}\text { TIDAK } \\
\text { BERSERTIFIKASI }\end{array}$ & LENGKAP & DITERAPKAN & YA \\
\hline 4. & TERAKREDITASI & BERSERTIFIKASI & $\begin{array}{c}\text { TIDAK } \\
\text { LENGKAP }\end{array}$ & DITERAPKAN & TIDAK \\
\hline 5. & TERAKREDITASI & BERSERTIFIKASI & LENGKAP & $\begin{array}{c}\text { TIDAK } \\
\text { DITERAPKAN }\end{array}$ & YA \\
\hline
\end{tabular}

Aturan-aturan inilah yang akan menjadi dasar dalam perhitungan sistem fuzzy nanti. Hal ini akan dijabarkan berikutnya. Inferensi fuzzy adalah metode bagaimana nilai tegas dari hasil implikasi aturan-aturan fuzzy dihasilkan. Inferensi fuzzy inilah yang menjadi kunci performa dalam pemrosesan suatu sistem fuzzy. Dengan kata lain inferensi inilah yang membuat suatu perhitungan fuzzy menghasilkan nilai yang dapat digunakan dalam kondisi nyata. Ada banyak sekali inferensi fuzzy, namun pada penelitian ini metode yang akan digunakan adalah metode Fuzzy Tsukamoto.

Berikut ini adalah tahapan - tahapan analisis fuzzy dalam inferensinya yang akan dipaparkan sebagai berikut:

\section{Fuzzifikasi}

Proses fuzzyfikasi merupakan perhitungan nilai crisp atau nilai input menjadi derajat keanggotaan. Perhitungan dalam proses fuzzyfikasi berdasarkan batas-batas fungsi keanggotaan (Restuputri, mahmudy, \& Cholissodin, 2015). Berikut ini adalah fungsi keanggotaan himpunan fuzzy dengan 4 kriteria input:

1. Standar Satuan Pendidikan; Terdiri atas 2 himpunan Fuzzy, yaitu TERAKREDITASI dan TIDAK TERAKREDITASI (Grafik 1)

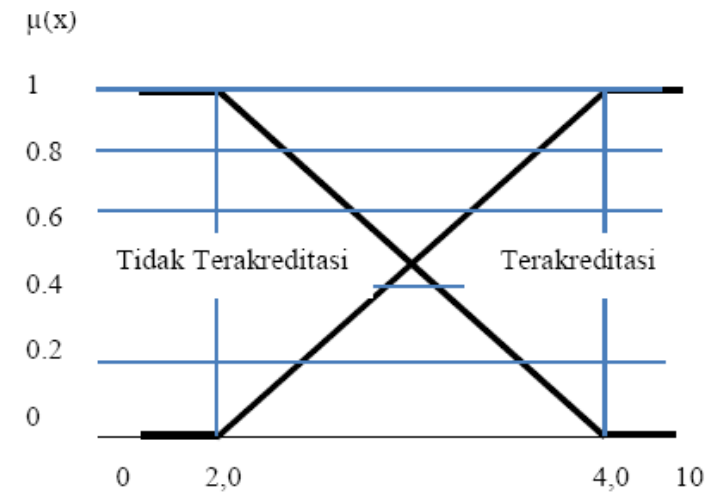


Grafik 1. Fungsi keanggotaan Variable Standar Satuan Pendidikan

Derajat Keanggotaan Tidak Terakreditasi:

$$
\begin{aligned}
& { }_{\text {Terakreditasi }}{ }^{[x]}=\left\{\begin{array}{l}
1 \quad ; \mathrm{x} \leq 2,0 \\
4.0-\mathrm{x} \\
-2,0-2,0
\end{array}\right. \\
& 0 \quad ; \quad x \leq 4,0
\end{aligned}
$$

Derajat Keanggotaan Terakreditasi:

$$
\mu \text { Terakreditasi }^{|x|}= \begin{cases}1 \quad ; x \geq 4,0 \\ x-2,0 \\ -\frac{1}{4,0-2,0} & 2,0 \leq x \leq 4,0 \\ 0 ; & x \geq 2,0\end{cases}
$$

Derajat keanggotaan untuk himpunan Fuzzy Standar Satuan Pendidikan adalah sebagai berikut:

$\mu$ TIDAK TERAKREDITASI $[3,0]=(4,0-3,0) / 4,0-2,0$

$$
=0,5
$$

$\mu$ TERAKREDITASI $[3,0] \quad=(3,0-2,0) / 4,0-2,0$

$$
=0,5
$$

2. Standar Guru dan Tendik; Terdiri atas 2 himpunan Fuzzy, yaitu BERSERTIFIKASI dan TIDAK BERSERTIFIKASI (Grafik 2)

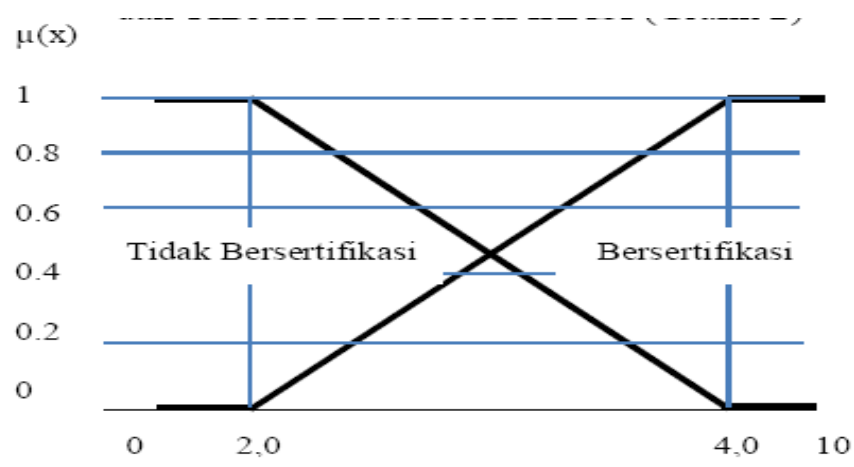

Grafik 2. Fungsi keanggotaan Variable Standar Guru dan Tendik 
Derajat keanggotaan Tidak Bersertifikasi:

$$
\begin{aligned}
& \mu \text { Tidak } \\
& \text { Bersertifikasi }{ }^{[x]}
\end{aligned} \begin{cases}1 \quad ; x \leq 2,0 \\
4,0-x & \\
-4,0-2,0 & 2,0 \leq x \leq 4,0 \\
0 \quad ; x \leq 4,0\end{cases}
$$

Derajat Keanggotaan Bersertifikasi:

$$
\mu \text { Bersertifikasi }|x|^{|x|} \begin{cases}1 & ; x \geq 4,0 \\ x-2,0 & \\ -4,0-2,0 & 2,0 \leq x \leq 4,0 \\ 0 \quad ; & x \geq 2,0\end{cases}
$$

Derajat keanggotaan untuk himpunan Fuzzy Standar Guru dan Tendik adalah sebagai berikut: $\mu$ TIDAK BERSERTIFIKASI $[3,0]=(4,0-3,0) / 4,0-2,0$

$$
=0,5
$$

$\mu$ BERSERTIFIKASI $[3,0] \quad=(3,0-2,0) / 4,0-2,0$

$$
=0,5
$$

3. Standar Sarana dan Prasarana; Terdiri atas 2 himpunan Fuzzy, yaitu LENGKAP dan TIDAK LENGKAP (Grafik 3)

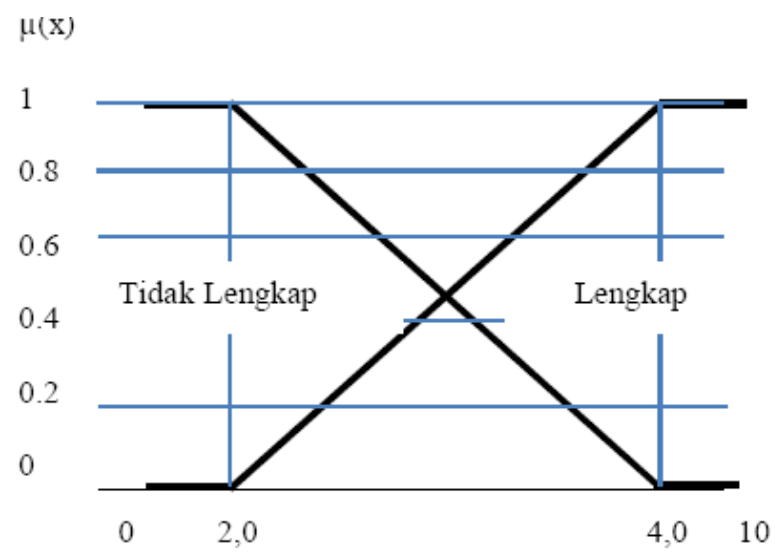

Grafik 3. Fungsi keanggotaan Variable Standar Sarana dan Prasarana 
Derajat keanggotaan Tidak Lengkap:

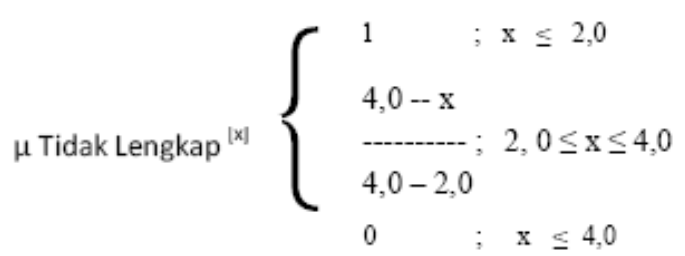

Derajat Keanggotaan Lengkap:

$$
\mu \text { Lengkap }^{[x]} \begin{cases}1 & ; \\ x-2,0 & x \geq 4,0 \\ -4,0-2,0 & 2,0 \leq x \leq 4,0 \\ 0 \quad ; & x \geq 2,0\end{cases}
$$

4. Derajat keanggotaan untuk himpunan Fuzzy Standar Sarana dan Prasarana adalah sebagai berikut:

$$
\begin{array}{ll}
\mu \text { TIDAK LENGKAP }[3,0] & =(4,0-3,0) / 4,0-2,0 \\
& =0,5 \\
\mu \text { LENGKAP }[3,0] & =(3,0-2,0) / 4,0-2,0 \\
& =0,5
\end{array}
$$

5. Standar Kerjasama; Terdiri atas 2 himpunan Fuzzy, yaitu DITERAPKAN dan TIDAK DITERAPKAN (Grafik 4) 


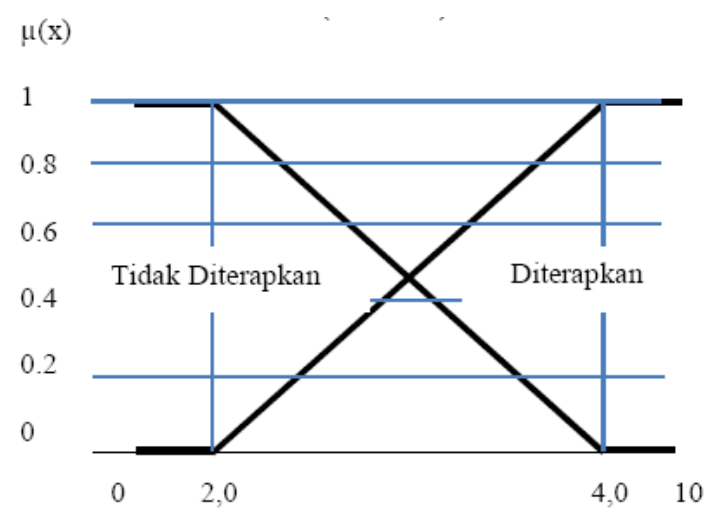

Grafik 4. Fungsi keanggotaan Variable Standar Sarana dan Prasarana Derajat keanggotaan Tidak Diterapkan:

$$
\mu \text { Tidak Siap }{ }^{|x|}= \begin{cases}1 & ; x \leq 2,0 \\ 4,0-x & \\ \frac{4,0-2,0}{4} & 2,0 \leq x \leq 4,0 \\ 0 & ; x \leq 4,0\end{cases}
$$

Derajat Keanggotaan Diterapkan:

$$
\mu \operatorname{Siap}^{|x|}= \begin{cases}1 & ; x \geq 4,0 \\ x-2,0 & \\ \hdashline 4,0-2,0 & 2,0 \leq x \leq 4,0 \\ 0 ; & x \geq 2,0\end{cases}
$$

Derajat keanggotaan untuk himpunan Fuzzy Standar Kerjasama adalah sebagai berikut:

$$
\begin{aligned}
\mu \text { TIDAK DITERAPKAN }[3,0]= & (4,0-3,0) / 4,0-2,0 \\
= & 0,5
\end{aligned}
$$

Derajat keanggotaan untuk himpunan Fuzzy Standar Kerjasama adalah sebagai berikut:

$\mu$ TIDAK DITERAPKAN $[3,0]=(4,0-3,0) / 4,0-2,0$

$$
=0,5
$$

$\mu$ DITERAPKAN $[3,0] \quad=(3,0-2,0) / 4,0-2,0$

$$
=0,5
$$

\subsubsection{Mesin Inferensi}

Pada mesin inferensi, kita terapkan fungsi MIN untuk setiap aturan pada aplikasi fungsi implikasi.

\begin{tabular}{llllll}
\hline Rule & Standar Satuan & Standar Guru & Standar & Standar & Kesiapan \\
\hline
\end{tabular}




\begin{tabular}{|c|c|c|c|c|c|}
\hline & Pendidikan & dan Tendik & $\begin{array}{c}\text { Sarana dan } \\
\text { Prasarana }\end{array}$ & Kerjasama & \\
\hline 1. & TERAKREDITASI & BERSERTIFIKASI & LENGKAP & DITERAPKAN & $\overline{Y A}$ \\
\hline 2. & $\begin{array}{c}\text { TIDAK } \\
\text { TERAKREDITASI }\end{array}$ & BERSERTIFIKASI & LENGKAP & DITERAPKAN & TIDAK \\
\hline 3. & TERAKREDITASI & $\begin{array}{c}\text { TIDAK } \\
\text { BERSERTIFIKASI }\end{array}$ & LENGKAP & DITERAPKAN & YA \\
\hline 4. & TERAKREDITASI & BERSERTIFIKASI & $\begin{array}{c}\text { TIDAK } \\
\text { LENGKAP }\end{array}$ & DITERAPKAN & TIDAK \\
\hline 5. & TERAKREDITASI & BERSERTIFIKASI & LENGKAP & $\begin{array}{c}\text { TIDAK } \\
\text { DITERAPKAN }\end{array}$ & YA \\
\hline
\end{tabular}

[R1] IF Standar Satuan Pendidikan TERAKREDITASI AND Standar Guru dan Tendik BERSERTIFIKASI AND Standar Sarana dan Prasarana LENGKAP Standar Kerjasama DITERAPKAN THEN Kesiapan = YA

Operator yang digunakan adalah AND, Sehingga:

$\alpha$-Kesiapan $=\mu$ TERAKREDITASI $\Omega \mu$ BERSERTIFIKASI $\Omega \mu$ LENGKAP $\Omega \mu$ DITERAPKAN $\mu$ DITERAPKAN) $=\min (\mu$ TERAKREDITASI $\Omega$ HBERSERTIFIKASI $\Omega \mu$ LENGKAP $\Omega$ $=\min (0,5 ; 0,5)$

$=0,5$

Himpunan SIAP pada grafik keanggotaan variable Predikat YA adalah sebagai berikut:

$(z-2,0) / 4,0-2,0 \quad=0,5$

Jadi, Nilai $z 1$ adalah 3,0

[R2] IF Standar Satuan Pendidikan TIDAK TERAKREDITASI AND Standar Guru dan Tendik BERSERTIFIKASI AND Standar Sarana dan Prasarana LENGKAP Standar Kerjasama DITERAPKAN THEN Kesiapan = TIDAK

Operator yang digunakan adalah AND, Sehingga:

a-Kesiapan $=\mu$ TIDAK TERAKREDITASI $\Omega \mu$ BERSERTIFIKASI $\Omega \mu$ LENGKAP $\Omega$ $\mu$ DITERAPKAN

$\mu$ DITERAPKAN)

$=\min (\mu$ TERAKREDITASI $\Omega \quad \mu$ BERSERTIFIKASI $\Omega \mu$ LENGKAP $\Omega$

$=\min (0,5 ; 0,5)$

$=0,5$

Himpunan SIAP pada grafik keanggotaan variable Predikat TIDAK adalah sebagai berikut:

$\begin{array}{ll}(4,0-z) / 4,0-2,0 & =0,5 \\ z & =3,0\end{array}$

Jadi, Nilai $z 2$ adalah 3,0

[R3] IF Standar Satuan Pendidikan TERAKREDITASI AND Standar Guru dan Tendik TIDAK BERSERTIFIKASI AND Standar Sarana dan Prasarana LENGKAP Standar Kerjasama DITERAPKAN THEN Kesiapan = YA

J-SISKO TECH Vol. 3, No. 1, 2020: 148-162 
Operator yang digunakan adalah AND, Sehingga:

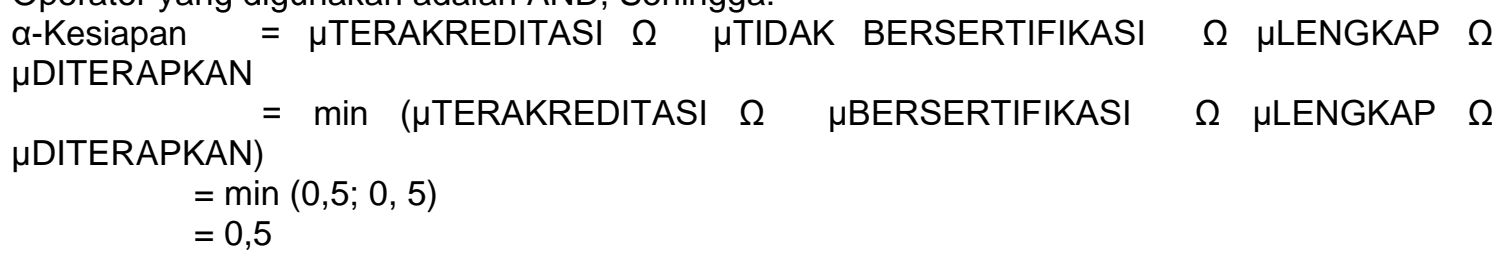

Himpunan SIAP pada grafik keanggotaan variable Predikat YA adalah sebagai berikut:

$\begin{array}{cl}(z-2,0) / 4,0-2,0 & =0,5 \\ z & =3,0\end{array}$

Jadi, Nilai $z 3$ adalah 3,0

[R4] IF Standar Satuan Pendidikan TERAKREDITASI AND Standar Guru dan Tendik BERSERTIFIKASI AND Standar Sarana dan Prasarana TIDAK LENGKAP Standar Kerjasama DITERAPKAN THEN Kesiapan = TIDAK

Operator yang digunakan adalah AND, Sehingga:

a-Kesiapan $=\mu$ TIDAK TERAKREDITASI $\Omega \mu$ BERSERTIFIKASI $\Omega \mu$ LENGKAP $\Omega$ $\mu$ DITERAPKAN

$=\min (\mu$ TERAKREDITASI $\Omega \mu$ BERSERTIFIKASI $\Omega \mu$ TIDAK LENGKAP $\Omega$ $\mu$ DITERAPKAN)

$$
\begin{aligned}
& =\min (0,5 ; 0,5) \\
& =0,5
\end{aligned}
$$

Himpunan SIAP pada grafik keanggotaan variable Predikat TIDAK adalah sebagai berikut:

$$
\begin{array}{cl}
(4,0-z) / 4,0-2,0 & =0,5 \\
z & =3,0
\end{array}
$$

Jadi, Nilai $z 4$ adalah 3,0

[R5] IF Standar Satuan Pendidikan TERAKREDITASI AND Standar Guru dan Tendik BERSERTIFIKASI AND Standar Sarana dan Prasarana LENGKAP Standar Kerjasama TIDAK DITERAPKAN THEN Kesiapan = YA

Operator yang digunakan adalah AND, Sehingga:

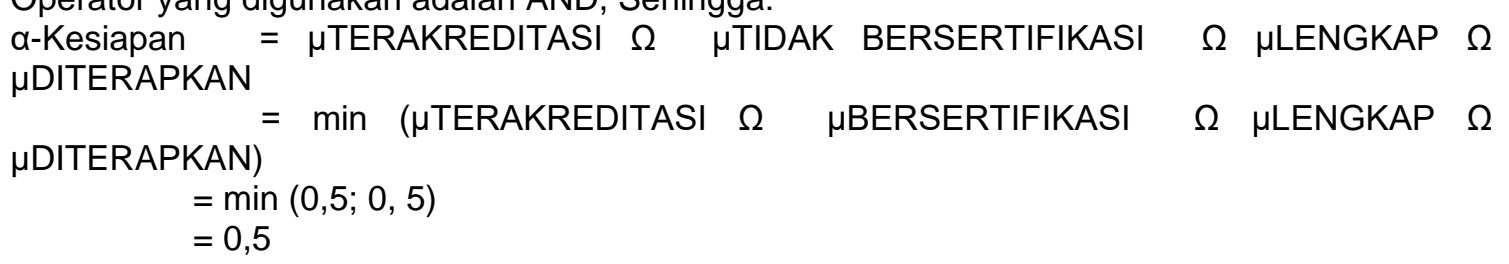

Himpunan SIAP pada grafik keanggotaan variable Predikat YA adalah sebagai berikut:

$\begin{array}{cc}(z-2,0) / 4,0-2,0 & =0,5 \\ z & =3,0\end{array}$

Jadi, Nilai $z 5$ adalah 3,0

\subsubsection{Defuzzifikasi}

Nilai tegas $z$ dapat dicari menggunakan rata - rata terbobot, yaitu:

$z=\quad \operatorname{apred}_{1}{ }^{*} Z_{1}+\operatorname{apred}_{2}{ }^{*} Z_{2}+\operatorname{apred}_{3}{ }^{*} Z_{3} \operatorname{apred}_{4}{ }^{*} Z_{4}$ 


$$
\begin{aligned}
& \text { apred }_{1+} \text { apred }_{2}+\text { apred }_{3}+\text { apred }_{4} \\
= & \frac{0,5^{*} 0.5+0,5^{\star} 0.5+0,5^{\star} 0.5+0,5^{\star} 0.5}{0.5+0.5+0.5+0.5} \\
= & 0.5
\end{aligned}
$$

\section{Jadi, nilai tegas $\mathbf{z}$ yang dihasilkan adalah 0.5}

\section{KESIMPULAN}

Kesimpulan dalam penelitian ini adalah sebagai berikut:

1. Memberikan khasanah pengetahuan bagi peneliti ilmu pakar Fuzzy tsukamoto

2. Terciptanya tujuan kurikulum Aceh sebagai panduan kurikulum kearifan lokal untuk menunjang pembelajaran sekolah menengah kejuruan.

3. Menjadi patokan bagi dinas - dinas pendidikan terkait sebagai bahan refrensi dalam menentukan kesiapan kurikulum aceh

\section{UCAPAN TERIMA KASIH}

Berisikan ucapan terima kasih kepada ibu Hj Hamidah, suami Muhammad Faisal dan anak tercinta Ali Hafuza Latif yang telah mendukung dalam menyelesaikan penelitian ini.

\section{REFERENSI}

[1]. Calon Fasilitator TOT IN 2 Implementasi program 2013 untuk kepala sekolah dan pengawas.

[2]. Dewi, S.K. dan Hartati, S. 2010, Integrasi Neuro-Fuzzy Sistem Fuzzy dan Jaringan Saraf Tiruan, Graha Ilmu, Yogyakarta.

[3]. Kusumadewi, Sri. Msgstr "Menggunakan Fuzzy - Decision Support Logic". Yogyakarta: Graha Ilmu, 2011, hlm. 23.9.

[4]. Kusumadewi, Sri. "Pengantar Kecerdasan Buatan". Yogyakarta: Graha Science, 2011, BAB 7.

[5]. Kurinasih, Imas dan Berlin Sani (B). 2014. Keberhasilan implementasi kurikulum 2013: Berbagai aspek kurikulum 2013 dipahami oleh Surabaya: kata-kata Pena.

[6]. Lampiran IV, Peraturan Menteri Pendidikan dan Kebudayaan Republik Indonesia, No. 81A 2013, tentang implementasi pedoman tentang kurikulum magang umum.

[7]. Lazim M, 2013, Aplikasi Fisik Pendekatan Ilmiah untuk Program Pembelajaran 2013, Yogyakarta, 2013.

[8]. Nana Syaodih Sukmadinata. (2000). Teori dan praktik pengembangan kurikulum. Bandung: PT Remaja Rosdakarya.

[9]. PPPPTK-SB Yogyakarta, (2013), materi pelatihan untuk implementasi Program Supervisi Sekolah 2013, penerbit Kementerian Pendidikan dan Kebudayaan Indonesia, Jakarta 2013

[10]. PPPPTK SB Yogyakarta. 2013. Bahan Ajar "Pendekatan dan Strategi Pembelajaran".

[11]. Peraturan No. 81A dari Menteri Pendidikan dan Kebudayaan Republik Indonesia tahun 2013 tentang pelaksanaan Program 2013.

[12]. Qanun Aceh nomor 9 tahun 2015 tentang implementasi pendidikan di provinsi Aceh.

[13]. Riandi Rahmat Nugraha, 2011, Aplikasi logika fuzzy untuk menghitung tunjangan harian, kurikulum teknik IT, ITB Bandung, Dokumen Struktur Diskrit IF2091 - Sem. I tahun $2011 / 2012$.

[14]. Sugiyono, 2009. Metode penelitian komersial (kualitatif, kuantitatif dan penelitian dan pendekatan pengembangan). Band: Alfabeta.

[15]. T. Autojo, S. Si., M.Kom. "Kecerdasan buatan". Semarang: ANDI Yogyakarta dan UDINUS Semarang, 2010. 